\title{
ANALISIS KESIAPAN MAHASISWA KOTA MEDAN SEBAGAI BAGIAN DARI BONUS DEMOGRAFI DALAM ERA MASYARAKAT EKONOMI ASEAN (MEA)
}

\author{
Farihah, Dwi Wahyuni Nurwihastuti, dan Apiek Gandamana \\ Surel: farihah34@gmail.com
}

\begin{abstract}
Students as part of the 2/3 of the Indonesian population on demographic bonuses have to prepare themselves not to become foreign in their own country in this era of MEA. The way to improve the quality of education and student skills so that later after college can compete in getting a job with other college graduates in ASEAN countries. Medan City is a student city in North Sumatra Province, this indication is marked by many higher education institutions. The number of private and public universities in Medan is 60 universities. Students from these universities come from various regions in North Sumatra Province with various qualities. The objectives of this research are: (1) To know the readiness of the students as part of the demographic bonus if viewed from the aspect of knowledge and understanding towards MEA (ASEAN Economic Community), (2) To know the readiness of the students as part of the demographic bonus when viewed in terms of skill to MEA (ASEAN Economic Community), and (3) Knowing the readiness of the students as part of the demographic bonus when viewed from the experience point of the MEA (ASEAN Economic Community). The results showed that the readiness of students as part of the demographic bonus when viewed in terms of knowledge and understanding of the MEA provides a fairly promising picture. Most students show considerable knowledge and understanding of the MEA itself. Student readiness as part of the demographic bonus in terms of skills still needs to be improved. Students in the city of Medan do not have adequate skills evenly so can be worried about having difficulties in facing the MEA. While the readiness of students as part of the demographic bonus when viewed in terms of experience has not described the maximum results. Students are generally still minimal experience. Therefore, there is still a need to improve further experience in creating students who are full of experience. Whether you realize it or not, it's an experienced student who can compete in the MEA era.
\end{abstract}

Keywords: students, Medan City, demographic bonus, MEA

\section{PENDAHULUAN}

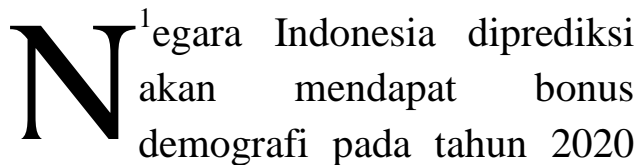
hingga 2030. Bonus demografi terjadi ketika negara Indonesia memiliki jumlah penduduk usia produktif dengan jumlah yang melimpah, yaitu sekitar $2 / 3$ dari

*Dr. Farihah, M.Pd. Dosen FT Unimed

*Dr. Dwi Wahyuni Nurwihastuti, M.Si.

Dosen FIS Unimed.

*Apiek Gandamana, S.Pd., M.Pd. Dosen

FIP Unimed. jumlah penduduk keseluruhan. Bonus demografi dapat dilihat dengan parameter dependency ratio (angka beban ketergantungan) yang cukup rendah, yaitu mencapai 44 . Hal ini berarti bahwa dalam setiap 100 penduduk usia produktif (15-64 tahun) hanya menanggung sekitar 44 penduduk tidak produktif. Data Badan Pusat Statistik (BPS) Indonesia tahun 2010 menunjukkan dependency ratio Indonesia sebesar 50,5. Sementara pada tahun 2015 dependency ratio memiliki angka lebih kecil yaitu 48,6. Angka 
dependency ratio ini akan semakin kecil lagi pada tahun 2020 hingga 2030, yang akan menciptakan bonus demografi untuk Indonesia.

Bonus demografi yang akan diterima Indonesia pada tahun 20202030 merupakan peluang untuk mencapai pertumbuhan ekonomi yang tinggi. Tingkat pertumbuhan ekonomi yang tinggi tersebut dapat terwujud jika penduduk yang produktif tersebut berkualitas. Pemerintah Indonesia harus mampu menyiapkan penduduk produktif sebagai sumberdaya manusia yang berkualitas. Salah satu cara menyiapkan sumberdaya manusia yang berkualitas yaitu dengan peningkatan kualitas pendidikan.

Peluang untuk meningkatkan kesejahteraan masyarakat melalui bonus demografi dapat juga menjadi permasalahan besarbagi Indonesia. Hal ini dapat terjadi ketika pemerintah Indonesia tidak siap dalam menyongsong bonus demografi pada tahun 2020-2030. Masalah yang terjadi apabila pemerintah tidak memanfaatkan bonus demografi dari awal maka bonus yang menguntungkan itu bisa terganggu oleh penduduk usia tua, di atas 60-65 tahun. Apabila keadaan ekonomi penduduk usia tua tersebut rendah, pendapatannya di masa usia kerja rendah, dan tidak mempunyai tabungan, penduduk tersebut akan menimbulkan beban ketergantungan secara ekonomi yang berat. Keadaan ini akan mempersempit keuntungan yang bisa diperoleh dari bonus, atau membengkaknya jumlah penduduk yang makin dewasa pada usia kerja. Permasalahan lainyang dapat terjadi ketika pemerintah Indonesia tidak mampu menyiapkan angkatan kerja dengan sumberdaya manusiayang berkualitas, maka akan terjadi peningkatan jumlah pengangguran. Pengangguran terjadi ketika angkatan kerja tidak mampu terserap kedalam lapangan kerja yang sebenarnya tersedia karena tidak memenuhi kualifikasi yang dibutuhkan perusahaan.

Mahasiswa merupakan penduduk usia produktif sehingga merupakan bagian dari bonus demografi. Dengan demikian perlu usaha peningkatan kualitas mahasiswa sehingga nanti dapat menjadi sumberdaya manusia yang berkualitas. Pendidikan yang berkualitas sangat dibutuhkan untuk menciptakan sumberdaya manusia yang terampil, mumpuni, dan profesional. Pendidikan menduduki posisi sentral dalam pembangunan saat ini karena sasaranya adalah peningkatan kualitas sumberdaya manusia.

Era Masyarakat Ekonomi ASEAN(MEA) telah dimulai pada akhir tahun 2015. Era ini merupakan masa pasar tenaga kerja tidak lagi berputar di dalam negeri tetapi sudah lintas negara. Indonesia mempunyai beberapa persoalan mendasar dalam rangka menghadapi MEA 2015. Pertama, masih tingginya jumlah 
pengangguran terselubung (disguised unemployment). Kedua, rendahnya jumlah wirausahawan baru untuk mempercepat perluasan kesempatan kerja. Ketiga, pekerja Indonesia didominasi oleh pekerja tidak terdidik sehingga produktivitas mereka rendah. Keempat, meningkatnya jumlah pengangguran tenaga kerja terdidik, akibat ketidaksesuaian antara lulusan perguruan tinggi dengan kebutuhan pasar tenaga kerja. Kelima, ketimpangan produktivitas tenaga kerja antar sektor ekonomi. Keenam, sektor informal mendominasi lapangan pekerjaan dan sektor ini belum mendapat perhatian optimal dari pemerintah. Ketujuh, pengangguran di Indonesia merupakan pengangguran tertinggi dari 10 negara anggota ASEAN, termasuk ketidaksiapan tenaga kerja terampil dalam menghadapi MEA 2015. Kedelapan, tuntutan pekerja terhadap upah minimum, tenaga kontrak, dan jaminan sosial ketenagakerjaan. Kesembilan, masalah Tenaga Kerja Indonesia (TKI) yang banyak tersebar di luar negeri.

Mahasiswa sebagai bagian dari 2/3 jumlah penduduk Indonesia pada bonus demografi sudah harus mempersiapkan diri agar tidak menjadi asing di negara sendiri pada era MEA ini. Caranya dengan meningkatkan kualitas pendidikan dan skill mahasiswa agar nanti setelah lulus kuliah mampu bersaing dalam mendapatkan pekerjaan dengan lulusan perguruan tinggi lainnya di negara ASEAN. Kota Medan merupakan kota pelajar di Provinsi Sumatera Utara, indikasi ini ditandai dengan banyak institusi pendidikan tinggi. Jumlah perguruan tinggi swasta dan negeri yang ada di Kota Medan adalah 60 perguruan tinggi. Mahasiswa dari perguruan tinggi tersebut berasal dari berbagai daerah di Provinsi Sumatera Utara dengan kualitas yang beragam.

Berdasarkan uraian di atas, maka yang menjadi tujuan dalam penelitian ini adalah:

1. Mengetahui kesiapan mahasiswa sebagai bagian dari bonus demografi jika dilihat dari segi pengetahuan dan pemahaman terhadap MEA (Masyarakat Ekonomi ASEAN).

2. Mengetahui kesiapan mahasiswa sebagai bagian dari bonus demografi jika dilihat dari segi keterampilan terhadap MEA (Masyarakat Ekonomi ASEAN).

3. Mengetahui kesiapan mahasiswa sebagai bagian dari bonus demografi jika dilihat dari segi pengalaman terhadap MEA (Masyarakat Ekonomi ASEAN).

\section{METODE}

Metode pengumpulan data menggunakan metode survey. Menurut Sugiyono (2009), metode survey digunakan untuk mendapatkan data dari tempat tertentu yang alamiah (bukan 
buatan), tetapi peneliti melakukan perlakuan dalam pengumpulan data, misalnya dengan mengedarkan kuesioner, test, wawancara terstruktur, dan sebagainya. Penggunaan metode survey akan memudahkan peneliti untuk memperoleh data untuk diolah dengan tujuan memecahkan masalah yang menjadi tujuan akhir suatu penelitian. Adapun langkah-langkah yang bisa dilakukan dalam pelaksanaan survey menurut Singarimbun (2011) adalah: 1) Merumuskan masalah penelitian dan menentukan tujuan survei; 2) Menentukan konsep dan hipotesa serta menggali kepustakaan; 3) pengambilan sampel; 4) Pembuatan kuesioner; 5) Pekerjaan lapangan; 6) Pengolahan data; 7) Analisa dan pelaporan.

Penggunaan metode survey untuk mempermudah peneliti melaksanakan penelitian, pada metode penelitian menjelaskan mengenai prosedur penelitian yang akan dilaksanakan sebagai cara ilmiah untuk mendapatkan data dengan tujuan dan kegunaan tertentu. Tujuan metode penelitian untuk mencari informasi data penelitian dari pertanyaan dapat terungkap secara faktual dan terperinci yang menggambarkan fenomena yang ada.

Adapun penelitian yang peneliti lakukan mengenai analisis kesiapan mahasiswa Kota Medan sebagai bagian dari bonus demografi dalam era Masyarakat Ekonomi
ASEAN. Sesuai dengan permasalahan yang diteliti, maka peneliti menggunakan metode peneltian yaitu pendekatan kuantitatif dengan alasan metode ini dianggap tepat, karena hal sesuai dengan pernyataan Sugiyono (2009) "Bahwa penelitian kuantitatif dapat diartikan sebagai metode penelitian yang berlandaskan pada filsafat positvisme, digunakan untuk meneliti pada populasi atau sampel tertentu, random, pengumpulan data mengggunakan instrumen penelitian, analisis data bersifat kuantitatif atau statistik dengan tujuan untuk menguji hipotesis yang telah ditetapkan". Dalam pengolahan data, peneliti menggunakan teknik analisis data statistik. Teknik ini digunakan peneliti karena pengumpulan data dilakukan dengan cara penyebaran quesioner dan cara pengolahannya dengan perhitungan presentase.

\section{Populasi dan Sampel}

Pengertian Populasi menurut Sugiyono (2009) mengungkapkan bahwa "Populasi adalah wilayah generalisasi yang terdiri atas obyek atau subyek yang mempunyai kualitas dan karakteristik tertentu yang ditetapkan oleh peneliti untuk dipelajari dan kemudian ditarik kesimpulannya, jadi populasi bukan hanya orang, tetapi juga obyek dan benda-benda alam lain. Populasi juga bukan sekedar jumlah yang ada pada obyek atau subyek yang dipelajari, tetapi meliputi seluruh 
karakteristik atau sifat yang dimiliki oleh subyek atau obyek itu". Dengan demikian yang menjadi populasi dalam penelitian ini adalah10 PTN/PTS di Kota Medan.

Sampel menurut Sugiyono (2009) adalah "Bagian dari jumlah dan karakteristik yang dimiliki oleh populasi tersebut". Teknik sampling random sederhana digunakan jika populasi bersifat homogen. Secara sederhana karena cara pengambilan sampel dari semua anggota populasi dilaksanakan secara acak tanpa melihat strata atau tingkatan yang terdapat dalam populasi. Teknik sampling random sederhana digunakan apabila populasi bersifat homogen, sederhana karena cara pengambilan sampel dari semua anggota populasi dilaksanakan secara acak tanpa melihat tingkatan yang ada pada populasi. Dengan demikian yang menjadi sampel dalam penelitian ini adalah 220 orang mahasiswa dari 11 PTN/PTS di Kota Medan.

\section{Teknik Pengumpulan Data}

Teknik pengumpulan data yang digunakan dalam penelitian ini sebagai berikut.

\section{Observasi}

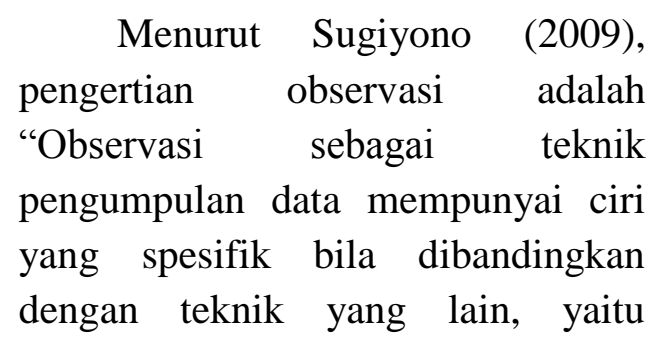

wawancara dan kuesioner. Kalau wawancara dan kuesioner selalu berkomunikasi dengan orang, maka observasi tidak terbatas pada orang, tetapi juga obyek-obyek alam yang lain”. Menurut Sutrisno Hadi (1986) dalam Sugiono (2009), “observasi merupakan suatu proses yang kompleks, suatu proses yang tersusun dari berbagai proses biologis dan psikologis. Dua diantara yang terpenting adalah proses-proses pengamatan dan ingatan".

Teknik observasi digunakan bila, penelitian berkenaan dengan prilaku manusia, proses kerja, gejalagejala alam dan bila respon yang diamati tidak terlalu besar. Menurut Sugiyono (2009), "teknik pengumpulan data dengan observasi digunakan bila, penelitian berkenaan dengan perilaku manusia, proses kerja, gejala-gejala alam dan bila responden yang diamati tidak terlalu besar, dari segi proses pelaksanaan pengumpulan data, observasi dapat dibedakan menjadi participant observation (observasi berperan serta) dan non participant observation".

\section{Kuesioner}

Menurut Sugiyono (2009), "Kuesioner merupakan teknik pengumpulan data yang dilakukan dengan cara memberi seperangkat pertanyaan atau pernyataan tertulis kepada responden untuk dijawabnya. Kuesioner merupakan teknik pengumpulan data yang efisien bila peneliti tahu dengan pasti variabel 
yang akan diukur dan tahu apa yang bisa diharapkan dari responden cukup besar dan tersebar di wilayah yang luas. Kuesioner dapat berupa pertanyaan tertutup atau terbuka, dapat diberikan kepada responden secara langsung.

Uma Sekaran (1992) dalam Sugiyono (2009) mengemukakan bahwa "Beberapa prinsip dalam penulisan angket sebagai teknik pengumpulan data yaitu: prinsip penulisan, pengukuran dan penampilan fisik".

\section{Wawancara}

Esterberg sebagaimana dikutip oleh Sugiono (2008) mendefinisikan wawancara sebagai berikut, " $a$ meeting of two persons to exchange information and idea through question and respons, resulting in communication and joint construction of meaning about a particular topic". Wawancara adalah merupakan pertemuan dua orang untuk bertukar informasi dan ide melalui tanya-jawab, sehingga dapat dikonstruksikan makna dalam suatu topik tertentu.

\section{Studi Dokumentasi}

Studi Dokumentasi dalam penelitian ini bertujuan untuk mendukung dan memberikan ketegasan hasil observasi dan kuisioner, serta data-data lain yang berkaitan dengan masalah yang diteliti. Dokumentasi ini sebagai alat dalam mengumpulkan data. Studi dokumen terpeniliti laksanakan pada saat observasi dan penyebaran angket/kuisioner.

\section{Penyusunan Alat Pengumpulan \\ Data}

Penyusunan alat pengumpulan data ini dibahas mengenai hal-hal yang berhubungan dengan penyusunan pengumpulan data. Penyusunan alat pengumpulan data dibahas mengenai intrumen yang akan dipakai dan langkahlangkahnya:

\section{Penyusunan Kisi-kisi Instrumen Penelitian}

Penyusunan kisi-kisi intrumen penelitian dilaksanakan secara sistematis sesuai dengan perumusan masalah, tujuan penelitian, hipotesis dan variabel penelitian yang dilakukan dijabarkan.

\section{Penyusunan Angket}

Penyusunan angket pada penelitian, setiap pertanyaan dalam angket ini merupakan penjabaran dan indikator-indikator yang akan dijadikan pertanyaan. Penyusunan angket tersebut adalah sebagai berikut.

Kisi-kisi instrument dapat dijadikan menjadi pedoman pembuatan angket.

a. Membuat daftar pertanyaan berdasarkan kisi-kisi instrumen, disusun secara singkat, padat dan jelas untuk memudahkan responden.

b. Membuat alternatif jawaban. 
c. Membuat petunjuk pengisian angket untuk menghindari kesalahan dalam pengisian angket.

d. Membuat surat pengantar angket agar responden mengetahui maksud dan tujuan pelaksanaan pengisian angket.

\section{Penyusunan Wawancara}

Wawancara dilakukan oleh peneliti karena ingin mengetahui lebih dalam permasalahan yang diteliti.

\section{Prosedur Pengumpulan Data}

\section{Tahapan Persiapan}

Tahapan persiapan terdiri dari: mempersiapkan, memperbanyak angket dan pedoman wawancara yang sudah disediakan dan mempersiapkan surat izin penyebaran angket dan menentukan hari untuk pengumpulan data.

\section{Tahapan Pelaksanaan}

Tahapan pelaksanaan adalah menyebarkan angket, pengambilan angket, dan melakukan wawancara.

\section{Tahap akhir}

Tahap akhir ini angket sudah diisi oleh responden. Kemudian diambil kembali dari setiap responden secara langsung.

\section{Proses Pengumpulan, Pengolahan, dan Analisis Data}

\footnotetext{
Proses pengumpulan, pengolahan dan analisis data penelitian secara garis besar dapat dipaparkan sebagai berikut.
}

a. Pengumpulan dan verifikasi data, yaitu cek jawaban responden

b. Pemberian skor yaitu memberikan skor pada setiap jawaban responden untuk setiap item.

c. Tabulasi data yaitu mentabulasi data sesuai variabel penelitian.

d. Menghitung ukuran statistik terhadap hasil pengukuran variabel penelitian seperti: proporsi atau presentasi, rata rata, simpangan baku dan varians.

e. Analisis data yaitu: menganalisis data yang sudah dikelompokan berdasarkan variabel penelitian sesuai masalah yang dibahas dengan hipotesis yang diajukan sehingga bisa mengarah pada pengambilan keputusan.

f. Penyajian data yaitu: mendeskripsikan data yang telah diolah dan dianalisis dalam bentuk uraian dan penyajian tabeltabel, sehingga permasalahan yang dibahas dan digambarkan secara jelas.

g. Pengujian hipotesis yaitu pengujian terhadap hipotesis yangdiajukan dan diuji menurut perhitungan statistik yang sesuai.

h. Penafsiran hasil analisis dan pengujian hipotesis penelitian yaitu: menafsirkan data yang telah diolah, dianalisis, dan disajikan. Kemudian dikaitkan dengan hipotesis statistik.

i. Penyimpulan dan pembahasan yaitu menyimpulkan hasil penelitian kemudian dihubungkan dengan pendapat-pendapat dan 
teori-teori serta pengalaman empirik.

\section{Teknik Pengolahan dan Analisis Data}

Pada teknik pengolahan data dilakukan dengan menggunakan cara kuantitatif dengan menggunakan metode deskriptif analitik.

\section{HASIL}

Penelitian telah dilakukan di 3 universitas negeri dan 7 universitas swasta di kota Medan. Universitas negeri di Medan hanya ada 3 yaitu: Universitas Negeri Medan (UNIMED), Universitas Sumatera Utara (USU), dan Universitas Islam Negeri Sumatera Utara (UIN-SU). Sedangkan universitas swasta di Medan diambil sampel 7, yaitu: Universitas Muhammadiyah Sumatera Utara (UMSU), Universitas Medan Area (UMA), Universitas Al-Hikmah, Universitas Islam Sumatera Utara (UISU), STIKPE, Universitas Panca Budi, Universitas Pembinaan Masyarakat Indonesia Medan, dan Universitas Sari Mutiara Indonesia Medan. Responden setiap universitas ada 20 orang yang berasal dari beberapa fakultas di setiap universitas. Dengan demikian, jumlah seluruh responden ada 220 orang.

Analisis dilakukan terhadap beberapa aspek, meliputi: (1) Pemahaman tentang bonus demografi, (2) pemahaman tentang MEA, (3) nilai IPK, (4) matakuliah yang disukai, (5) matakuliah yang tidak disukai, (6) kemampuan bahasa Inggris, (7) kemampuan bahasa asing lainnya selain bahasa Inggris, (8) unit kegiatan mahasiswa/ komunitas mahasiswa yang diikuti, (9) pengalaman organisasi 5 tahun terakhir, (10) pengalaman mengikuti seminar 5 tahun terakhir, (11) pengalaman mengikuti pelatihan formal, (12) pengalaman mengikuti pelatihan informal, (13) pengalaman mengikuti PKM (Program Kreativitas Mahasiswa), (14) penguasaan IT dan software, (15) keterampilan/skill yang dimiliki, (16) prestasi akademik dan non akademik yang dimiliki, (17) pengalaman ke luar negeri, dan (18) beasiswa yang pernah diterima.

\section{Kesiapan Pengetahuan dan}

\section{Pemahaman Mahasiswa Kota}

Medan dalam menghadapi MEA

Kesiapan mahasiswa jika dilihat dari segi pengetahuan dan pemahaman dapat diukur melalui hal-hal sebagai berikut: (1) pemahaman tentang bonus demografi, (2) pemahaman tentang MEA, (3) nilai IPK sebagai acuan kemampuan akademik, matakuliah yang disukai, matakuliah yang tidak disukai, dan (6) prestasi akademik dan non akademik. Berdasarkan hasil penelitian dapat dijelaskan bahwa kesiapan mahasiswa jika dilihat berdasarkan pengetahuan dan pemahaman cukup menjanjikan. Hal ini diperleh berdasarkan gambaran 
capaian jawaban responden terhada pertanyaan yang diajukan. Tingkan jawaban mahasiswa secara umum berada dalam kategori baik. Jika ditelaah lebih lanjut, pengetahuan dan pemahaman mahasiswa yang cukup tinggi itu tergambar juga dari rerata IPK mahasiswa yang berada di atas 3,00. Namun, disadari atau tidak, pada kenyataannya masih banyak mahasiswa yang merasa kurang suka dengan 1 matakuliah tertentu. Persoalan semacam ini dalah suatu hal yang lumrah karena minat dan motivasi seseorang terhadap matakuliah tertentu berbeda. Prestasi akademik dan non akademik juga merupakan indikator kesiapan pengetahuan dan pemahaman mahasiswa terhadap MEA masih rendah, yang ditandai sebagian besar mahasiswa Kota Medan tidak memiliki prestasi.

\section{Pemahaman tentang Bonus Demografi}

Terdapat 4 pertanyaan yang diajukan kepada responden terkait dengan analisis pemahaman mahasiswa tentang bonus demografi, antara lain: (1) apa yang dimaksud dengan bonus demografi?, (2) kapan Indonesia akan mendapatkan bonus demografi?, (3) manfaat apa yang akan diperoleh Indonesia jika mendapatkan bonus demografi?, dn (4) kerugian apa yang akan dialami Indonesia jika tidak mampu memanfaatkan bonus demografi? Hasil analisis jawaban responden dapat dilihat pada tabel 3.1 berikut.

Tabel 3.1 Hasil Analisis Pemahaman Mahasiswa tentang Bonus Demografi

\begin{tabular}{|c|c|c|c|c|}
\hline Kualifikasi & SB & B & C & K \\
\hline Jumlah & 86 & 68 & 37 & 29 \\
\hline Persentase & $39 \%$ & $31 \%$ & $17 \%$ & $13 \%$ \\
\hline
\end{tabular}

Berdasarkan tabel 4.1 di atas dapat dilihat bahwa terdapat 86 orang (39\%) dengan pemahaman yang Sangat Baik (SB), 68 orang (31\%) dengan pemahaman yang Baik (B), 37 orang (17\%) dengan pemahaman yang Cukup Baik (C), dan 29 orang (13\%) dengan pemahaman yang baik. Berdasarkan hasil analisis tersebut diperoleh gambaran bahwa terdapat $70 \%$ dari seluruh jumlah responden yang sudah paham dengan baik tentang bonus demografi dan terdapat $30 \%$ yang masih perlu peningkatan pemahaman lebih lanjut tentang bonus demografi.

\section{Pemahaman tentang MEA}

Analisis pemahaman mahasiswa tentang MEA dilakukan dengan mengajukan 4 pertanyaan seputar konsep MEA itu sendiri. Pertanyaan yang diajukan antara lain: (1) Apa yang dimaksud dengan MEA (Masyarakat Ekonomi 
Asean)?, (2) Kapan era MEA berlangsung?, (3) Manfaat apa yang akan diperoleh Indonesia melalui MEA?, dan (4) Kerugian apa yang akan dialami Indonesia melalui MEA? Hasil analisis terhadap jawaban responden dapat dilihat pada tabel 3.2 berikut.

Tabel 3.2 Hasil Analisis Pemahaman Mahasiswa tentang MEA

\begin{tabular}{|c|c|c|c|c|}
\hline Kualifikasi & SB & B & C & K \\
\hline Jumlah & 75 & 68 & 48 & 29 \\
\hline Persentase & $34 \%$ & $31 \%$ & $22 \%$ & $13 \%$ \\
\hline
\end{tabular}

Berdasarkan tabel di atas dapat dijelaskan bahwa terdapat 75 orang (34\%) yang mempunyai pemahaman yang Sangat Baik (SB) tentang MEA, 68 orang (31\%) yang mempunyai pemahaman yang Baik (B) tentang MEA, 48 orang (22\%) yang mempunyai pemahaman yang Cukup Baik (C) tentang MEA, dan 29 orang $(13 \%)$ yang mempunyai pemahaman yang Kurang Baik (K) tentang MEA. Merujuk pada data tersebut dapat disimpulkan bahwa terdapat $65 \%$ dari total keseluruhan jumlah responden yang mempunyai pemahaman yang baik tentang MEA, sedangkan 35\% lagi masih perlu peningkatan pemahaman lebih lanjut tentang MEA.

\section{Nilai IPK}

Hasil analisis IPK mahasiswa dikelompokkan menjadi 4 bagian utama, yaitu: (1) IPK >3,50, (2) IPK 3,00-3,50, (3) IPK 2,50-2,99, dan (4) IPK <250. Untuk lebih jelasnya dapat dilihat pada tabel 3.3 berikut.

Tabel 3.3 Hasil Analisis IPK Mahasiswa

\begin{tabular}{|c|c|c|c|c|}
\hline IPK & $\mathbf{3 , 5 0}$ & $\mathbf{3 , 0 0}-\mathbf{3 , 5 0}$ & $\mathbf{2 , 5 0}-\mathbf{2 , 9 9}$ & $<\mathbf{2 , 5 0}$ \\
\hline Jumlah & 108 & 92 & 11 & 9 \\
\hline Persentase & $49 \%$ & $42 \%$ & $5 \%$ & $4 \%$ \\
\hline
\end{tabular}

Berdasarkan tabel di atas, dapat dijelaskan bahwa kemampuan akademik mahasiswa yang menjadi responden bervariasi. Terdapat 108 orang (49\%) dengan IPK >3,50, 92 orang (42\%) dengan IPK 3,00-3,50, 11 orang $(5 \%)$ dengan IPK 2,502,99, dan 9 orang (4\%). Mengacu pada data tersebut, tergambar bahwa yang menjadi responden dengan IPK $>3,00$ cukup tinggi, yaitu $91 \%$. Sedangkan IPK yang <3,00 hanya $9 \%$ dari total keseluruhan.

\section{Matakuliah yang Disukai}

Hasil analisis terhadap matakuliah yang disukai dikelompokkan berdasarkan banyaknya matakuliah. Banyaknya matakuliah dikelompokkan menjadi 4 bagian, yaitu: (1) $\geq 3 \mathrm{MK}$, (2) 2 MK, (3) 1 MK, dan (4) 0 MK. Hasil analisis dapat dilihat pada tabel 3.4 berikut. 
Tabel 3.4 Hasil Analisis Banyak Matakuliah yang Disukai Mahasiswa

\begin{tabular}{|c|c|c|c|c|}
\hline Banyak MK & $\geq 3$ MK & 2 MK & 1 MK & 0 MK \\
\hline Jumlah & 37 & 106 & 75 & 2 \\
\hline Persentase & $17 \%$ & $48 \%$ & $34 \%$ & $1 \%$ \\
\hline
\end{tabular}

MK = Matakuliah

Berpedoman pada isi tabel di atas, dapat dijelaskan bahwa terdapat 37 orang $(17 \%)$ yang menyukai $\geq 3$ MK, 106 orang (48\%) yang menyukai $2 \mathrm{MK}, 75$ orang $(34 \%)$ yang hanya menyukai $1 \mathrm{MK}$, dan 2 orang $(1 \%)$ yang tidak menyukai satu pun matakuliah. Berdasarkan hasil analisis tersebut diperoleh gambaran bahwa setiap mahasiswa mempunyai minimal 1 matakuliah yang disukai selama proses perkuliahan dan hanya
2 orang saja yang tidak mempunyai satu pun matakuliah yang disukai.

\section{Matakuliah yang Tidak Disukai}

Pengelompokan hasil analisis terhadap banyak matakuliah yang tidak disukai hampir sama dengan matakuliah yang disukai, yaitu: (1) $\geq 3 \mathrm{MK}$, (2) $2 \mathrm{MK}$, (3) $1 \mathrm{MK}$, dan (4) 0 MK. Untuk lebih jelasnya dapat dilihat pada tabel 3.5 berikut.

Tabel 3.5 Hasil Analisis Banyak Matakuliah yang Tidak Disukai Mahasiswa

\begin{tabular}{|c|c|c|c|c|}
\hline Banyak MK & $\geq \mathbf{3}$ MK & 2 MK & 1 MK & 0 MK \\
\hline Jumlah & 7 & 0 & 136 & 77 \\
\hline Persentase & $3 \%$ & $0 \%$ & $62 \%$ & $35 \%$ \\
\hline
\end{tabular}

\section{MK = Matakuliah}

Berdasarkan tabel di atas, dapat ditelaah bahwa jumlah mahasiswa yang tidak menyukai $\geq 3$ MK ada 7 orang (3\%), yang tidak menyukai 2 MK tidak ada (0\%), yang tidak menyukai 1 MK cukup tinggi yaitu 136 orang (62\%), dan yang menyukai seluruh matakuliah ada 77 orang $(35 \%)$. Dengan demikian, dapat disimpulkan bahwa cukup tinggi persentase mahasiswa yang mempunyai minimal 1 matakuliah yang tidak disukai, yaitu mencapai 65\%, artinya lebih dari $50 \%$ mahasiswa rata-rata mempunyai minimal 1 matakuliah yang tidak disukai.

\section{Prestasi Akademik dan Non} Akademik yang Dimiliki

Hasil analisis prestasi akademik dan non akademik mahasiswa dapat dilihat pada tabel 3.6 berikut.

Tabel 3.6 Hasil Analisis Prestasi Akademik dan Non Akademik

\begin{tabular}{|c|c|c|c|c|}
\hline Banyak Prestasi & $\mathbf{2 3}$ & $\mathbf{2}$ & $\mathbf{1}$ & $\mathbf{0}$ \\
\hline Jumlah & 9 & 7 & 7 & 198 \\
\hline Persentase & $4 \%$ & $3 \%$ & $3 \%$ & $90 \%$ \\
\hline
\end{tabular}


Berdasarkan tabel di atas, dapat dijelaskan bahwa terdapat 9 orang (4\%) yang mempunyai $\geq 3$ prestasi, 7 orang (3\%) yang mempunyai 2 prestasi, 7 orang $(3 \%)$ yang mempunyai 1 prestasi, dan 198 orang $(90 \%)$ yang tidak mempunyai prestasi sama sekali.

Kesiapan

Keterampilan

Mahasiswa Kota Medan dalam menghadapi MEA

Kesiapan mahasiswa jika dilihat dari segi keterampilan dapat diukur melalui: (1) kemampuan berbahasa Inggris, (2) kemampuan berbahasa asing lainnya selain bahasa Inggris, (3) penguasaan IT dan Software, dan (4) keterampilan/skill lainnya. Jika merujuk pada hasil penelitian, aspekaspek yang diungkapkan masih perlu perhatian khusus dan bimbingan lebih lanjut. Hal ini dapat dilihat berdasarkan masih rendahnya kemampuan bahasa Inggris sebagian besar mahasiswa, rendahnya kemampuan berbahasa asing selain bahasa Inggris, rendahnya penguasaan IT dan software, dan rendahnya volume keterampilan/skill yang dimiliki setiap mahasiswa. Dengan demikian, jika dilihat dari segi keterampilan, kesiapan mahasiswa belum menggambarkan hasil yang cukup baik, artinya masih perlu pengembangan keterampilan lebih lanjut agar terhindar dari ketertinggalan dalam menghadapi MEA.

\section{Kemampuan Bahasa Inggris}

Hasil telaah terhadap kemampuan bahasa Inggris dikelompokkan berdasarkan 4 kualifikasi utama, yaitu Sangat Baik (SB), Baik (B), Cukup Baik (C), dan Kurang (K). Untuk lebih jelasnya dapat dilihat pada tabel berikut.

Tabel 3.7 Hasil Analisis Kemampuan Bahasa Inggris Mahasiswa

\begin{tabular}{|c|c|c|c|c|}
\hline Kualifikasi & SB & B & C & K \\
\hline Jumlah & 7 & 86 & 79 & 48 \\
\hline Persentase & $3 \%$ & $39 \%$ & $36 \%$ & $22 \%$ \\
\hline
\end{tabular}

Berdasarkan hasil analisis di atas diperoleh gambaran bahwa terdapat 7 orang $(3 \%)$ yang mempunyai kemampuan bahasa Inggris yang sangat baik, 86 orang (39\%) yang mempunyai kemampuan bahasa Inggris yang baik, 79 orang (36\%) yang mempunyai kemampuan bahasa Inggris yang cukup baik, dan 48 orang $(22 \%)$ yang mempunyai keterampilan bahasa Inggris yang masih kurang. Berdasarkan hasil telaah tersebut dapat disimpulkan bahwa lebih dari 50\% kemampuan bahasa Inggris mahasiswa masih perlu ditingkatkan lebih lanjut. 
Kemampuan Bahasa Asing

Lainnya Selain Bahasa Inggris

Hasil telaah terhadap selain bahasa Inggris dapat dilihat pada tabel 3.8 berikut.

kemampuan bahasa asing mahasiswa

Tabel 3.8 Hasil Analisis Kemampuan Bahasa Asing Selain Bahasa Inggris

\begin{tabular}{|c|c|c|c|c|}
\hline $\begin{array}{c}\text { Banyak } \\
\text { Bahasa Asing }\end{array}$ & $\geq \mathbf{3}$ BA & 2 BA & 1 BA & 0 BA \\
\hline Jumlah & 2 & 2 & 37 & 178 \\
\hline Persentase & $1 \%$ & $1 \%$ & $17 \%$ & $81 \%$ \\
\hline
\end{tabular}

\section{BA = Bahasa Asing}

Berdasarkan data di atas dapat dijelaskan bahwa terdapat 2 orang (1\%) yang mempunyai kemampuan berbahasa asing $\geq 3$ bahasa, 2 orang (1\%) juga yang mempunyai kemampuan berbahasa asing dengan 2 bahasa, 37 orang (17\%) yang mempunyai kemampuan 1 bahasa asing, dan 178 orang (81\%) yang tidak mempunyai kemampuan berbahasa asing selain dari bahasa Inggris.

\section{Penguasaan IT dan Software}

Hasil analisis kemampuan mahasiswa dalam penguasaan IT dan software daapat dilihat pada tabel 3.9 berikut.

\section{Tabel 3.9 Hasil Analisis Penguasaan IT dan Software}

\begin{tabular}{|c|c|c|c|c|}
\hline $\begin{array}{c}\text { Banyak } \\
\text { Penguasaan IT } \\
\text { \& Software }\end{array}$ & $\mathbf{2}$ & $\mathbf{2}$ & $\mathbf{1}$ & $\mathbf{0}$ \\
\hline Jumlah & 139 & 26 & 26 & 29 \\
\hline Persentase & $63 \%$ & $12 \%$ & $12 \%$ & $13 \%$ \\
\hline
\end{tabular}

Mengacu pada tabel di atas, dapat dijelaskan bahwa kemampuan penguasaan IT cukup baik, yaitu 139 orang $(63 \%)$ yang menguasai $\geq 3$ bidang IT, 26 orang (12\%) yang menguasai 2 bidang IT, 26 orang (12\%) yang hanya menguasai 1 bidang IT, dan 29 orang (13\%) yang tidak menguasai IT sama sekali.

\section{Keterampilan/ Skill yang Dimiliki}

Hasil analisis terhadap keterampilan/ skill mahasiswa dapat dilihat pada tabel 3.10 berikut.

Tabel 3.10 Hasil Analisis Keterampilan/ Skill

\begin{tabular}{|c|c|c|c|c|}
\hline $\begin{array}{c}\text { Banyak } \\
\text { Keterampilan }\end{array}$ & $\mathbf{2}$ & $\mathbf{2}$ & $\mathbf{1}$ & $\mathbf{0}$ \\
\hline Jumlah & 9 & 22 & 114 & 75 \\
\hline Persentase & $4 \%$ & $10 \%$ & $52 \%$ & $34 \%$ \\
\hline
\end{tabular}


Berpedoman pada tabel di atas dapat dijelaskan bahwa terdapat 9 orang (4\%) yang mempunyai $\geq 3$ keterampilan, 22 orang (10\%) yang mempunyai 2 keterampilan, 114 orang (52\%) yang mempunyai 1 keterampilan, dan 75 orang (34\%) yang tidak mempunyai keterampilan sama sekali.

\section{Kesiapan Pengalaman Mahasiswa Kota Medan dalam menghadapi MEA}

Kesiapan mahasiswa yang diukur melalui pengalaman dilihat melalui beberapa aspek, antara lain: unit kegiatan mahasiswa/ komunitas mahasiswa yang diikuti, pengalaman organisasi 5 tahun terakhir, pengalaman mengikuti seminar 5 tahun terakhir, pengalaman mengikuti pelatihan formal, pengalaman mengikuti pelatihan informal, pengalaman mengikuti PKM (Program Kreativitas
Mahasiswa), pengalaman ke luar negeri, dan beasiswa yang pernah diterima.

Berdasarkan hasil penelitian, secara umum digambarkan bahwa mahasiswa masih minim akan pengalaman. Jika dihubungkan dengan kesiapan dalam menghadapi MEA, mahasiswa direkomendasikan agar lebih meningkan pengalaman baik dalam bidang formal maupun informal. Dengan demikian, mahasiswa akan lebih siap menghadapi MEA yang terus semakin menghampiri. Disadari atau tidak, mahasiswa yang berpengalamanlah yang akan mampu dan siap menghadapi MEA secara kompetitif.

\section{Unit Kegiatan Mahasiswa/}

\section{Komunitas Mahasiswa yang}

Diikuti

Hasil telaah banyaknya unit kegiatan yang diikuti mahasiswa dapat dilihat pada tabel 3.11 berikut.

Tabel 3.11 Hasil Analisis UKM/ Komunitas yang Diikuti Mahasiswa

\begin{tabular}{|c|c|c|c|c|}
\hline $\begin{array}{c}\text { Banyak } \\
\text { UKM }\end{array}$ & $\geq \mathbf{3}$ UKM & 2 UKM & 1 UKM & 0 UKM \\
\hline Jumlah & 7 & 2 & 121 & 92 \\
\hline Persentase & $3 \%$ & $1 \%$ & $55 \%$ & $42 \%$ \\
\hline
\end{tabular}

UKM = Unit Kegiatan Mahasiswa

Berdasarkan tabel di atas, dapat dijelaskan bahwa terdapat 7 orang $(3 \%)$ yang mengikuti $\geq 3$ UKM, 2 orang (1\%) yang mengikuti kegiatan 2 UKM, 121 orang (55\%) yang mengikuti 1 UKM, dan 92 orang $(42 \%)$ yang tidak mengikuti UKM sama sekali. Berdasarkan hasil tersebut dapat disimpulkan bahwa lebih dari $50 \%$ mahasiswa yang mengikuti minimal 1 UKM setiap mahasiswa.

\section{Pengalaman Organisasi 5 Tahun Terakhir \\ Hasil telaah terhadap pengalaman organisasi mahasiswa dapat dilihat pada tabel 3.12 berikut.}


Tabel 3.12 Hasil Analisis Organisasi yang Diikuti Mahasiswa

\begin{tabular}{|c|c|c|c|c|}
\hline $\begin{array}{c}\text { Banyak } \\
\text { Organisasi }\end{array}$ & $\geq \mathbf{3}$ Or & 2 Or & 1 Or & 0 Or \\
\hline Jumlah & 9 & 9 & 107 & 95 \\
\hline Persentase & $4 \%$ & $4 \%$ & $49 \%$ & $43 \%$ \\
\hline
\end{tabular}

\section{Or $=$ Organisasi}

Mengacu pada tabel di atas, dijelaskan bahwa terdapat 9 orang (4\%) yang mengikuti $\geq 3$ organisasi, 9 orang (4\%) yang mengikuti 2 organisasi, 107 orang (49\%) yang hanya mengikuti 1 organisasi, dan 95 orang $(43 \%)$ yang tidak mengikuti organisasi sama sekali. Dengan

cukup banyak mahasiswa yang tidak mengikuti organisasi sama sekali, yaitu mencapai $43 \%$.

\section{Pengalaman Mengikuti Seminar 5} Tahun Terakhir

Hasil telaah pengalaman mengikuti seminar 5 tahun terakhir dapat dilihat pada tabel 3.13 berikut. demikian, dapat disimpulkan bahwa

Tabel 3.13 Hasil Analisis Pengalaman Mengikuti Seminar Mahasiswa

\begin{tabular}{|c|c|c|c|c|}
\hline $\begin{array}{c}\text { Banyak } \\
\text { Seminar }\end{array}$ & $\mathbf{2}$ & $\mathbf{2}$ & $\mathbf{1}$ & $\mathbf{0}$ \\
\hline Jumlah & 0 & 0 & 77 & 143 \\
\hline Persentase & $0 \%$ & $0 \%$ & $35 \%$ & $65 \%$ \\
\hline
\end{tabular}

Berdasarkan tabel di atas, diperoleh gambaran bahwa tidak ada 1 orang mahasiswa pun yang mengikuti lebih dari 1 seminar. Hanya 77 orang $(35 \%)$ saja yang pernah mengikuti seminar, sedangkan 143 orang (65\%) lagi belum pernah mengikuti seminar.
Pengalaman Mengikuti Pelatihan Formal

Hasil telaah terhadap
pengalaman mengikuti pelatihan
formal dideskripsikan seperti yang
tertera pada tabel 3.14 berikut.

Tabel 3.14 Hasil Analisis Pengalaman Mengikuti Pelatihan Formal

\begin{tabular}{|c|c|c|c|c|}
\hline $\begin{array}{c}\text { Banyak } \\
\text { Pelatihan }\end{array}$ & $\mathbf{2 3}$ & $\mathbf{2}$ & $\mathbf{1}$ & $\mathbf{0}$ \\
\hline Jumlah & 0 & 0 & 11 & 209 \\
\hline Persentase & $0 \%$ & $0 \%$ & $5 \%$ & $95 \%$ \\
\hline
\end{tabular}

Berdasarkan tabel di atas diperoleh gambaran bahwa tidak 1 orang pun yang pernah mengikuti pelatihan formal. Yang telah pernah mengikuti pelatihan formal hanya sedikit yaitu hanya 11 orang (5\%), sedangkan 209 (95) lagi belum pernah sama sekali. 


\section{Pengalaman Mengikuti Pelatihan} Informal

Hasil analisis terhadap

pengalaman mengikuti pelatihan pelatihan formal. Untuk lebih jelasnya dapat dilihat pada tabel 3.15 berikut. informal hampir sama dengan

Tabel 3.15 Hasil Analisis Pengalaman Mengikuti Pelatihan Informal

\begin{tabular}{|c|c|c|c|c|}
\hline $\begin{array}{c}\text { Banyak } \\
\text { Pelatihan }\end{array}$ & $\mathbf{3}$ & $\mathbf{2}$ & $\mathbf{1}$ & $\mathbf{0}$ \\
\hline Jumlah & 0 & 0 & 18 & 202 \\
\hline Persentase & $0 \%$ & $0 \%$ & $8 \%$ & $92 \%$ \\
\hline
\end{tabular}

Berdasarkan tabel di atas, dpat dijelaskan bahwa hnaya 18 orang (8\%) yang pernah mengikuti pelatihan informal dan itu pun hanya 1 pelatihan, sedangkan sisanya 202 orang $92 \%$, belum pernah mengikuti pelatihan.

\section{Pengalaman Mengikuti PKM (Program Kreativitas Mahasiswa) Hasil telaah terhadap pengalaman mengikuti PKM dapat dilihat pada tabel 3.16 berikut.}

Tabel 3.16 Hasil Analisis Pengalaman Mengikuti PKM

\begin{tabular}{|c|c|c|c|c|}
\hline Banyak PKM & $\mathbf{2}$ & $\mathbf{2}$ & $\mathbf{1}$ & $\mathbf{0}$ \\
\hline Jumlah & 0 & 0 & 22 & 189 \\
\hline Persentase & $0 \%$ & $0 \%$ & $10 \%$ & $90 \%$ \\
\hline
\end{tabular}

Berdasarkan tabel di atas, terlihat bahwa hanya 22 orang $(10 \%)$ saja yang pernah mengikuti kegiatan PKM. Sementara 189 orang $(90 \%)$ lagi belum pernah mengikuti kegiatan PKM

Tabel 3.17 Hasil Analisis Pengalaman ke Luar Negeri

\begin{tabular}{|c|c|c|c|c|}
\hline $\begin{array}{c}\text { Banyak } \\
\text { Pengalaman }\end{array}$ & $\mathbf{2 3}$ & $\mathbf{2}$ & $\mathbf{1}$ & $\mathbf{0}$ \\
\hline Jumlah & 2 & 0 & 9 & 209 \\
\hline Persentase & $1 \%$ & $0 \%$ & $4 \%$ & $95 \%$ \\
\hline
\end{tabular}

Berdasarkan tabel di atas, dapat dijelaskan bahwa hanya 2 orang (1\%) yang mempunyai pengalaman ke luar negeri yang $\geq 3$ kali, 9 orang (4\%) yang 1 kali ke luar

\section{Pengalaman ke Luar Negeri}

Hasil analisis pengalaman mahasiswa ke luar negeri dapat dilihat pada tabel berikut. 
Tabel 3.18 Hasil Analisis Beasiswa yang Pernah Diterima

\begin{tabular}{|c|c|c|c|c|}
\hline $\begin{array}{c}\text { Banyak } \\
\text { Beasiswa }\end{array}$ & $\mathbf{2}$ & $\mathbf{2}$ & $\mathbf{1}$ & $\mathbf{0}$ \\
\hline Jumlah & 0 & 6 & 20 & 194 \\
\hline Persentase & $0 \%$ & $3 \%$ & $9 \%$ & $88 \%$ \\
\hline
\end{tabular}

Berdasarkan tabel di atas dapat dijelaskan bahwa hanya $12 \%$ saja yang pernah mendapat beasiswa, yaitu 26 orang dari total jumlah keseluruhan yang terdiri dari 6 orang 2 kali dan 20 orang 1 kali. Sedangkan sisanya sebanyak 194 orang $(88 \%)$ belum pernah mendapat beasiswa.

\section{KESIMPULAN}

Kesimpulan hasil penelitian ini adalah:

1. Kesiapan mahasiswa sebagai bagian dari bonus demografi jika dilihat dari segi pengetahuan dan pemahaman terhadap MEA (Masyarakat Ekonomi Asean) memberikan gambaran yang cukup menjanjikan. Sebagian besar mahasiswa menunjukkan pengetahuan dan pemahaman yang cukup besar terhadap MEA itu sendiri.

2. Kesiapan mahasiswa sebagai bagian dari bonus demografi jika dilihat dari segi keterampilan terhadap MEA (Masyarakat Ekonomi Asean) masih perlu ditingkatkan. Mahasiswa di kota Medan belum mempunyai keterampilan yang cukup memadai secara merata sehigga dapat dikhawatirkan mengalami kesulitan dalam menghadapi MEA.

3. Kesiapan mahasiswa sebagai bagian dari bonus demografi jika dilihat dari segi pengalaman terhadap MEA (Masyarakat Ekonomi Asean) belum menggambarkan hasil yang maksimal. Mahasiswa secara umum masih minim akan pengalaman. Oleh sebab itu, masih perlu peningkatan pengalaman lebih lanjut dalam menciptakan mahasiswa yang penuh akan pengalaman. Disadari atau tidak, mahasiswa yang berpengalamanlah yang mampu bersaing di era MEA.

\section{DAFTAR PUSTAKA}

Achsani, Noer Azam. Integrasi Ekonomi ASEAN+3; Antara Peluang dan Ancaman. The Brighten Institute. http://PPbrighten.or.id

Adhitama, Toeti Prahas. 2012. Memaknai Bonus Demogarfi. Media Indonesia, 20 Juli, hlm. 9 
Adioetomo, Sri Moertiningsih Setyo. 2005. Bonus Demografi Menjelaskan Hubungan Antara Pertumbuhan

Penduduk dengan

Pertumbuhan Ekonomi, Pidato Pengukuhan Guru Besar Tetap dalam Bidang Ekonomi Kependudukan pada Fakultas Ekonomi Universitas Indonesia

Anderson, J. E. 2003. Public Policymaking: An Introduction, Boston: Houghton Miffin Company, pp.1-34

Anonim. 2007. Survei Demografi dan Kesehatan Indonesia (SDKI). BPS

Anonim. 2012. Survei Demografi dan Kesehatan Indonesia (SDKI). BPS

Arifin, Samsul., Djaafara, Rizal A., dan Budiman, Aida S. 2008. Masyarakat Ekonomi ASEAN: Memperkuat Sinergi ASEAN di Tengah Kompetisi Global. Jakarta: PT. Elex Media Komputindo

Bardach, Eugene. 2012. A Practical Guide to Policy Analysis: The Eightfold Path to More Effetive Problem Solving. Sage dan CQ Press

Budiman, Aida S. 2012. Masyarakat Ekonomi ASEAN: Konsep Masyarakat Ekonomi ASEAN. Work Paper Direktorat Internasional, Jakarta.
Bloom, David E, David Canning, Jaypee Sevilla. 2003. The Demographic Deviden. Santa Monica: Pittsburgh

Dunn, W.N. 2003. Pengantar Analisis Kebijakan Publik. Yogyakarta: UGM Press

Fischer, F., Miller, G. J., dan Sidney, M. S. 2007. Handbook of Public Policy Analisis: Theory, Politics, and Methods. Boca Raton: CSR Press

Hill, Michael. 1993. The Policy Process. London: Harvester Wheatsheaf

Patton, carl. V dan Savicki, David. S. 1986. Basic Methods of Policy Analysis and Planning. New Jersey: Prentice Hall

Patton, carl. V dan Savicki, David. S. 1993. Basic Methods of Policy Analysis and Planning. Upper Saddle River, NJ: Prentice Hall

Sidney, Mara S. 2007. "Policy Formulation: Design and Tools" (79-101) in Fischer, Frank, Gerlad J. Miller, Mara S. Sydney (eds) Handbook of Public Policy Analysis: Theory, Politics and Methods. Taylor and Francis

Sugiyono. 2013. Metode Penelitian Pendidikan (Pendekatan Kuantitatif, Kualitatif, dan $R \& D)$. Bandung: Alfabeta 